Volume $11 \mid$ Issue 1

March 2020

\title{
Book Review: Suffer the Little Children: Genocide, Indigenous Nations, and the Canadian State
}

\author{
Alfred de Zayas \\ Former Secretary of the UN Human Rights Committee, UN Independent Expert on the Promotion of a Democratic and \\ Equitable International Order, alfreddezayas@gmail.com
}

Recommended Citation

de Zayas, A. (2020). Book review: Suffer the little children: Genocide, Indigenous nations, and the Canadian State. The International Indigenous Policy Journal, 11(1). doi: https://10.18584/iipj.2020.11.1.8355 


\title{
Book Review: Suffer the Little Children: Genocide, Indigenous Nations, and the Canadian State
}

\begin{abstract}
In this timely and morally necessary book, Tamara Starblanket gives particular attention to the forced transfer of Indigenous children to institutions whose raison d'être was to indoctrinate and "educate" them away from their culture and heritage so as to erase Indigenous memory and reprogram younger generations as "Canadians." These institutions were notorious for death and disease, torture, forced starvation, forced labour, and sexual predation. The book's structure is well-ordered, the argumentation compelling, but not in phoney "scholarly detachment," instead in conscious compilation and analysis of the evidence, supported by the force of ethics and a commitment to truth and justice, regardless of zeitgeist and political correctness.
\end{abstract}

\section{Keywords}

Indigenous rights, genocide, cultural genocide, residential schools, Canadian history, law, self-determination, colonial history

\section{Creative Commons License}

\section{(c) $(1) \Theta \Theta$}

This work is licensed under a Creative Commons Attribution-Noncommercial-No Derivative Works 4.0 License. 


\title{
Book Review: Suffer the Little Children: Genocide, Indigenous Nations, and the Canadian State
}

\author{
Starblanket, T. (2018). Suffer the little children: Genocide, Indigenous nations and the Canadian state. \\ Clarity Press. pp. 374. \$29.95 (paperback). ISBN 978-0-9986947-7-1.
}

There are books that should make us pause and reassess how we look at history and how it impacts today's world. Among such books are David Stannard's (1993) groundbreaking American Holocaust and Tamara Starblanket's dissertation, revealing the continuing process of physical and cultural extinction the Original Nations of North America. The potential of these books would be achieved if historians and the media were committed to comprehensive truth in the correct context and if they would abandon double standards, selective indignation, and that most effective weapon: silence. Damnatio memoriae [damnation of memory] occurred not only in Roman times (Benoist, 2007), it has been practiced by all civilizations. Ours continues the tradition through direct and indirect censorship.

An incisive foreword by history professor Ward Churchill and a strong Epilogue by international law expert Sharon Venne make this brilliant dissertation a political manifesto, a call for action to restore the human rights of the Original Nations of Canada, especially their right of self-determination, which has been and continues to be violated by the colonizers: the Canadian settler-society. In this timely and morally necessary book, Starblanket gives particular attention to the forced transfer of Indigenous children to institutions whose raison d'être was to indoctrinate and "educate" them away from their culture and heritage so as to erase Indigenous memory and reprogram younger generations as "Canadians." These institutions were notorious for death and disease, torture, forced starvation, forced labour, and sexual predation.

The book's structure is well-ordered, the argumentation compelling, but not in phoney "scholarly detachment," instead in conscious compilation and analysis of the evidence, supported by the force of ethics and a commitment to truth and justice, regardless of zeitgeist and political correctness. Starblanket begins by addressing the catastrophe that befell the Original Nations, victims of a relentless colonial assault on their existence as "peoples," characterized by massacres, expropriations, expulsions, and imposition of conditions of life prohibited by the letter and the spirit of the Convention on the Prevention and Punishment of the Crime of Genocide (1948). Starblanket puts emphasis not only on the physical destruction of peoples, but on the concept of cultural genocide, which was so important to Raphael Lemkin (1944), who coined the term "genocide" in 1944 and who clearly intended to have it apply to the attempt to destroy a people's culture, identity, and traditions. The states parties that adopted the Genocide Convention on December 9, 1948, however, intended to continue their colonial practices of cultural genocide and thus dropped the concept of denying a people the right to their own culture and way of life, although this very right is protected by the Constitution of UNESCO (1945) and by the subsequent UNESCO Convention on the Protection and Promotion of the Diversity of Cultural Expressions (2005).

In the Introduction, Starblanket addresses the wall of evasion and denial surrounding the ongoing crimes against Indigenous Peoples. She quotes Harold Cardinal, a survivor of the residential schools: "The policies adopted by Canada over the years with regard to Indians are not different from the rationale employed by Nazi Germany in its implementation of what is called the 'Final Solution' Residential schools were only one element" (p. 1). Yet, the rubrics of denial are many. 
Chapter 1 focuses on the definition of genocide and its application to Indigenous Peoples. Chapter 2 describes the deliberate policies of separating Indigenous children from their parents and the attempt at making true "Canadians" out of them. There are many "smoking guns" that point at the "intention" to destroy Indigenous cultures. As Duncan Campbell Scott, superintendent of the Department of Indian Affairs wrote: "I want to get rid of the Indian problem ... Our objective is to continue until there is not a single Indian in Canada that has not been absorbed into the body politic and there is no Indian question" (p. 1). One may add that Campbell Scott added insult to injury by referring to an "Indian" problem, when he meant the right of identity of the Original Nations of Canada-such as the Algonquin, the Cree, the Lingit, the Mi'kmaq, the Mohawk, the Oneida, and the Squamish—none of them inhabitants of the Indian subcontinent!

Chapter 3 reviews the history of Canada as a colonizing state and analyses the phenomenon of "cognitive conditioning" (p. 160). She cites an insightful study by Steven Newcomb (2011), ${ }^{1}$ director of the Indigenous Law Institute, on the United Nations Declaration on the Rights of Indigenous Peoples (2007) and "the Paradigm of Domination." It is important to understand the unseen assumptions in colonial law, the media, and academia concerning the Original Nations of North America and the use of metaphors:

"Cognitive theory enables us to realize that [western] law is the result of non-Indigenous cognitive processes, social practices and conventions, and cultural patterns, and of the way that members of the dominating society imaginatively project taken-for-granted categories and concepts onto indigenous peoples" of which the "overall effect has been the traumatic intergenerational domination of [Indigenous Peoples] existence.” (p. 161; brackets in original)

Chapter 4 is aptly titled Smoke and Mirrors: Canada's Pretence of Compliance with the Genocide Convention. Starblanket cites Eli Wiesel's famous book Night: "They are committing the greatest indignity human beings can inflict on one another: telling people who have suffered excruciating pain and loss that their pain and loss were illusions" (p. 206). Indeed, society and the media have been in denial of the crimes committed and still being committed against Indigenous Peoples. It is a kind of negationism, which, unlike the vulgar negationism of the Holocaust, is more or less socially acceptable in the US and Canada. Starblanket refers to the Genocide Convention and cites the five acts "committed with the intent to destroy, in whole or in part, a national, ethnical, racial or religious group, as such: a) killing members of the group; b) causing serious bodily or mental harm to member of the group; c) deliberately inflicting on the group conditions of life calculated to bring about its physical destruction in whole or in part; d) imposing measures intended to prevent births within the group; e) forcibly transferring children of the group to another group" (for the original text, see Convention on the Prevention and Punishment of the Crime of Genocide, 1948, Article II). She shows how these violations have been perpetrated against Indigenous Peoples. For example, she describes the forcible transfer of Indigenous children to the custody of non-Indigenous families, which Prime Minister Harper blandly referred to as "profoundly negative" and therefore "wrong" (p. 220). Yet, is "wrong" not a far cry from criminal? Is it a subterfuge to avoid the possibility of legal recourse and remedy?

\footnotetext{
${ }^{1}$ Newcomb is the author of Pagans in the Promised Land: Decoding the Doctrine of Christian Discovery, which has been a bestseller on Amazon. He is co-producer of the the Doctrine of Discovery: Unmasking the Domination Code, directed by Sheldon Wolfchild (Dakota).
} 
There is an urgent need to rehabilitate Indigenous communities and give them the necessary financing and space to allow them to reconstruct their lives and their future. Notwithstanding lip service to the rights of Indigenous Peoples and attempts to recognize rights through ILO Convention 169 and the UN Declaration on the Rights of Indigenous Peoples, there is little or no conviction behind governmental pronouncements and the ultimate goal remains the "assimilation" of the remaining Indigenous people after their respective cultures have been extinguished. There is something unnatural about the Government of Canada's Truth and Reconciliation Commission of Canada, which in a real sense constitutes "a safety valve, enabling recognition without facing legal culpability" (p. 363), because of the legal loopholes built-in and other intellectual manoeuvres.

Surely everyone needs truth-most urgently non-Indigenous people, 99\% of whom have no conception of the monstrous crimes committed and still being committed against Indigenous Peoples-not only in Canada, but in the United States, Brazil, Chile, Colombia, Guatemala, Honduras, and others. In her conclusion, Starblanket reminds us:

The non-Indigenous scholar is unable to conceive of his/her complicity in the brutal or destructive nature of colonialism, and furthermore cannot conceive that the problem exists in the society that allows horrific acts of violence against the innocent to continue. (p. 272)

One would think that "there is no sugar-coating genocide" (p. 270), but the fact is that suppression of information leads to suppression of thought, of empathy, of the inner voice that tells us that something must be done. Truth requires more than an "apology" followed by "business as usual," but also a commitment to try to make some sort of reparation. This reviewer strongly agrees with Starblanket's assessment:

So-called state solutions cloaked in euphemisms and rhetoric such as "reconciliation" only further the colonial agenda ... For Indigenous Peoples who have undergone genocidal acts, reconciliation is an oxymoron. The illusion that Indigenous Peoples are now achieving justice must be dispelled. (p. 274)

The problem remains that there is no genuine remorse, but only public relations exercises aimed at distracting attention and sowing confusion.

As with the Holocaust, all the billions of German marks and Euros paid by Germany to victims of Nazism cannot undo the atrocities, but at least it is recognition, not a cover-up or whitewash. It evidences that moral responsibility has been awoken. In the case of the descendants of the 10 million Indigenous people of North America (Denevan, 1992; Dobyns, 1966), there remains a legal and moral obligation to make reparation, which would amount to many billions (or even trillions) of dollars in compensation for the genocide that accompanied the deadliest "clash of civilizations."

The late UN Special Rapporteur of the Sub-Commission on Promotion and Protection of Human Rights, Professor Miguel Alfonso Martínez, expressed a caveat:

It is not possible to undo all that has been done... but this does not negate the ethical imperative to undo (even at the expense, if need be, of the straightjacket imposed by the 
unbending observance of the "rule of [non-Indigenous] law") the wrongs [crimes] done, both spiritually and materially, to the Indigenous Peoples. (p. 269; brackets in original)

I would like to be bolder and say that there must be a "road map" designed by Indigenous Peoples and supported by the Office of the UN High Commissioner for Human Rights to make rehabilitation and reparation happen.

The way ahead must be built on the imperative of implementing the right of self-determination for all peoples on this planet. As Professor Miguel Alfonso Martínez (1999) wrote in Study on Treaties, Agreements and Other Constructive Arrangements Between States and Indigenous Populations: Final Report, Indigenous Peoples are entitled to the inalienable right of self-determination, which is enshrined in Article 1 of the UN Charter, Article 1 of the Covenant on Civil and Political Rights, and Article 2 of the Covenant on Economic, Social and Cultural Rights. This right of (and not just "to") selfdetermination belongs to that category of peremptory international law principles known as jus cogens [compelling law]. My report to the UN General Assembly (de Zayas, 2013) quotes extensively from Alfonso Martinez's (1999) report. Along with my report to the General Assembly the following year (de Zayas, 2014), both reports are devoted entirely to the theory and practice of self-determination. My report to the Human Rights Council formulates 23 Principles of International Order, including the implementation of the right of self-determination as a conflict-prevention measure (de Zayas, 2018).

Throughout the book, Starblanket demonstrates a broad knowledge of both history and law. The documentation is vast and precise, as reflected in 79 pages of endnotes comprising more than a thousand reliable sources and commentary. The book challenges the reader to reassess mainstream "certainties" and "values" to test whether Western "enlightened" societies and mainstream human rights activists are practicing what they preach. The book holds a mirror to every reader and invites them to come to grips with fundamental issues of natural justice, exploitation, discrimination, humiliation, impunity for genocide, and crimes against humanity.

What can we learn from this book? Perhaps the bottom line is that colonization by the Europeans has never ended. There was no decolonization process like in Africa or Asia. To this day, the Indigenous Peoples of North America continue to live in a form of colonial subjugation and, unlike the peoples of Africa and Asia, the Original Nations of the United States and Canada were never restored to independence and prosperity. Partly, this is because the Original Nations were victims of physical genocide, and the European settlers - actually uninvited migrants_-became so numerous that Indigenous Peoples - the nations that had given the names to the continent-became minorities in their own lands and their natural resources were looted.

In a world plagued by fake news, fake history, and fake law, it is remarkable that this intellectually honest dissertation was accepted in a conformist academic environment. It is even more significant that Starblanket's necessary message has been published in book form. This gives reason for mitigated optimism. Her book is a tour de force, important not only for Indigenous Peoples, but especially for nonIndigenous people who may be moved to action based on the common humanity of all members of the human family and who believe that natural justice requires affirmative action to begin restoring Indigenous Peoples to a position that will guarantee the survival of their ancient culture and traditions. 
Perhaps Canada should consider nominating Indigenous traditions as the intangible cultural heritage of humankind (UNESCO, n.d.) and take the measures necessary to preserve them.

If a book ever deserved translation into the languages of other colonial states, surely Starblanket's study merits Spanish and French editions. Notwithstanding the excellent footnotes, a future English edition would benefit from a separate comprehensive bibliography, including pertinent UN resolutions and reports as well as the jurisprudence of the Inter-American Court of Human Rights. As a professor of history and international law, this reviewer would have taken pleasure being an advisor on a dissertation of this superb quality. I would have graded the dissertation summa cum laude [with highest praise].

\section{References}

Alfonso Martínez, M. (1999). Study on treaties, agreements and other constructive arrangements between States and Indigenous populations: Final report (UN Doc. E/CN.4/Sub.2/ 1999/20). https://digitallibrary.un.org/record/276353? $\ln =\mathrm{en}$

Benoist, S. (2007). Mémoire et histoire: Les procédures de condamnation dans l'antiquité romaine [Memory and history: Conviction procedures in Roman antiquity]. Centre régional universitaire lorrain d'histoire.

The Constitution of UNESCO, November 16, 1945, http://portal.unesco.org/en/ev.php-

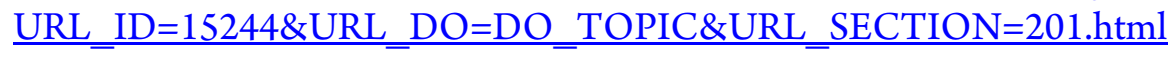

Convention on the Prevention and Punishment of the Crime of Genocide, December 9, 1948, https://www.ohchr.org/en/professionalinterest/pages/crimeofgenocide.aspx

Convention on the Protection and Promotion of the Diversity of Cultural Expressions, October 20, 2005, https://en.unesco.org/creativity/sites/creativity/files/passeport-convention2005web2.pdf

de Zayas, A. (2013). Report of the Independent Expert on the Promotion of a Democratic and Equitable International Order (A/68/284). Retrieved from https://documents-ddsny.un.org/doc/UNDOC/GEN/N13/421/23/PDF/N1342123.pdf?OpenElement

de Zayas, A. (2014). Interim report of the Independent Expert on the Promotion of a Democratic and Equitable International Order (A/69/272). Retrieved from https://documents-ddsny.un.org/doc/UNDOC/GEN/N14/497/95/PDF/N1449795.pdf?OpenElement

de Zayas, A. (2018). Report of the Independent Expert on the Promotion of a Democratic and Equitable International Order (A/HRC/37/63). Retrieved from https://documents-ddsny.un.org/doc/UNDOC/GEN/G18/018/46/PDF/G1801846.pdf?OpenElement

Denevan, W. (1992). Native American populations in 1492: Recent research and a revised hemispheric estimate. In W. Denevan (Ed.), The Native population of the Americas in 1492 (pp. xvii-xxx). University of Wisconsin Press. 
Dobyns, H. F. (1966). An appraisal of techniques with a new hemispheric estimate. Current Anthropology, 7(4), 395-416.

Lemkin, R. (1944). Axis rule in occupied Europe. The Lawbook Exchange Ltd.

Newcomb, S. T. (2011). The UN Declaration on the Rights of Indigenous Peoples and the paradigm of domination. Griffiths Law Review, 20(3), 578-607.

Stannard, D. E. (1993). American Holocaust. Oxford University Press.

UNESCO. (n.d.). What is intangible cultural heritage? https://ich.unesco.org/en/what-is-intangible$\underline{\text { heritage-00003 }}$

United Nations Declaration on the Rights of Indigenous Peoples, September 13, 2007, https://www.un.org/development/desa/indigenouspeoples/declaration-on-the-rights-ofindigenous-peoples.html

Venne, S. (1998). Our Elders understand our rights: Evolving international law regarding Indigenous Peoples' rights. Theytus Books. 